\title{
Inbreeding in sugarcane varieties
}

\author{
Autofecundação em variedades de cana-de-açúcar
}

\section{Marcelo de Almeida Silva' Paulo de Souza Gonçalves ${ }^{I I}$}

\begin{abstract}
Sugarcane species are allogamous, i.e. selfing is expected to reduce plant vigor. This study was undertaken to obtain and evaluate first-generation inbred lines that may be used for further crosses and determine the extent of inbreeding depression in sugarcane. In this research, 26 parental varieties were self-pollinated to obtain about 19,000 seedlings. Results showed that it is possible to segregate different traits in a given variety and find lines with promising outcome for all assessed characteristics. The soluble solids segregation observed in low and even high-Brix varieties increases the possibility of quick improvement in this trait. Self-pollination did not produce a general loss in yield traits such as soluble solids, stalk number and stalk diameter in any of the 26 varieties, but both stalk height and stalk weight showed strong inbreeding depression. Selfing-derived clones can be used to produce hybrid vigor in crossings.
\end{abstract}

Key words: Saccharum spp., endogamy, hybrids, pollination, soluble solids.

\section{RESUMO}

Cana-de-açúcar tem sido considerada como uma planta alógama e, por esta razão, a autofecundação deveria produzir uma redução no vigor das plantas. $O$ objetivo deste estudo foi obter e avaliar a primeira geração de linhas autofecundadas que podem ser usadas em mais cruzamentos $e$ também determinar a extensão da depressão causada por essa autofecundação em cana-de-açúcar. Neste trabalho, 26 variedades utilizadas como parentais foram autofecundadas, das quais se obtiveram cerca de 19.000 plântulas. Os resultados mostraram que é possível segregar diferentes características em uma dada variedade sem perder vigor e encontrar progênies com características superiores. A segregação observada para
Brix \% em variedades de baixo, $e$ até mesmo nas de alto Brix, aumenta a possibilidade de melhoramento dessa característica. Autofecundação não produziu uma perda geral nos atributos de produção nas 26 variedades estudadas, mas a altura e massa de colmos apresentaram forte depressão por endogamia. Clones derivados de autofecundação podem ser usados para produzir vigor híbrido nos cruzamentos.

Palavras-chave: Saccharum spp., endogamia, híbridos, polinização, sólidos solúveis.

\section{INTRODUCTION}

The effects of selfing and the use of pure lines developed by selfing after successive generations in breeding have been widely studied in a number of simple diploids. In the pioneer research, the most spectacular yield increases were obtained by using hybrids involving two or more selfed lines in maize. A vigor decrease in the early stages of pure line development, before homozygosity is reached, is often observed (ALLARD, 1971). With crossing, vigor is restored in a hybrid specific combining/crossing. Superiority can be attributed to the accumulation of dominant effect genes (dominance hypothesis) or to the heterozygotic condition at several loci of favorable characteristic (over dominance hypothesis) (HALLAUER, 1990).

The inbreeding approach in sugarcane (Saccharum spp.) has been considerably

IAgência Paulista de Tecnologia dos Agronegócios (APTA), Pólo Centro-Oeste, CP 66, 17201-970, Jaú, SP, Brasil.

E-mail: marcelosilva@apta.sp.gov.br. Autor para correspondência.

IIPrograma Seringueira, Instituto Agronômico de Campinas (IAC), Campinas, SP, Brasil. 
controversial. STEVENSON (1953) concentrated selfing studies in Barbados, and WARNER (1953) worked on outbreeding in Hawaii representing the two breeding strategy extremes adopted in sugarcane improvement. Inbreeding programs were also successful in Australia (MCINTYRE \& JACKSON, 2001), Canal Point (STEVENSON, 1965), India (ETHIRAJAN et al., 1978) and Colombia (CASSALETT et al., 1996).

Self-pollination in most cross-pollinated crops produces weak plants. In general, the sexual seeds obtained by this means do not germinate very well (AMAYA, 1986). That is why, while crossing sugarcane, self-pollination is actively avoided by physical treatment, as it is believed that a reduction in vigor could occur (CASSALETT et al., 1996). Although sugarcane has a great cytological complexity, and a slower and indirect selfing process, there is no theoretical reason which demonstrates that superior genotypes cannot be obtained through selfpollination.

Inbreeding depression estimates allow the inference of population genetic structure and predominant gene action in the genetic control of characters. It is important to verify the selection viability of higher plants in segregated and clone-derived populations. In the absence of over dominance in the genetic control of characters, it is theoretically possible to select recombinant individuals with superior performance than the parental clone, within the segregated populations derived from clones. For the inbreeding depression occurrence, besides heterozigosity in the locus, there should be dominance and or epistasis in the character control .

According to VEGA (1988), crosses between inbred lines produce high gains although hybrid vigor may also be obtained in crosses between varieties, as in sugarcane. Sugarcane varieties have the advantage of vegetative propagation, which keeps the hybrid combinations. This type of propagation also facilitates genotype selection within a family as a modification of gamete selection instead of the normal family selection.

As a possible means to overcome the ceiling on sugarcane production, this research was initiated with a group of parental varieties to obtain and evaluate first-generation inbred lines that may be used for further crosses and to determine also the extent of inbreeding depression.

\section{MATERIAL AND METHODS}

Twenty-six varieties were chosen for the selfing study. Self-pollinations were conducted at the Centro de Tecnologia Canavieira (CTC) experiment station in Camamu, Bahia, Brazil. At flowering, stalks were isolated in the crossing house to avoid foreign pollen and obtain only self-pollinated seeds. All varieties set seeds. Seeds were germinated in boxes containing vermiculite at APTA Regional Centro-Oeste Development and Research Station in Jaú (22 $17^{\circ}$ S; 48³4' W; 580m altitude), São Paulo State, Brazil.

After one month, seedlings were transplanted to a nursery and kept for 60 days before transplanting to the field. Seedlings (F2) and their parents were set out in a randomized complete block design with 26 treatments each, totalizing 52 treatments, with four replications, with row spacing of $0.5 \mathrm{~m}$ and $1.5 \mathrm{~m}$ between rows. Plots comprised four rows of $5.0 \mathrm{~m}$, in a total of 44 seedlings per plot. The parental plot comprised four rows $x 2.0 \mathrm{~m}$, because of the varietal genetic stability, in a total of 20 plants from single buds.

Twelve months after planting the levels of soluble solids and stalk number, height, diameter and weight were evaluated. Millable stalks were counted in each plot. Bundle weight of five stalks in the field was recorded for each plot, according methodology by LANDELL \& SILVA (2004) modified for this trial to get a minimum number of stalks. Mean stalk weight $(\mathrm{kg})$ was estimated by dividing bundle weight by 5 . A ruler was used to measure stalk height in five-stalk samples. A Vernier caliper was used to measure the diameter of the same samples at the first third of the stalk (bottom). Soluble solids means were obtained by direct sugarcane juice readings in ten and eight randomly chosen stalks from self and parents respectively. The different amount of number of stalks for self and parents for the soluble solids analysis was due to difference between the genetic stability of the plants from self and parents. A stalk puncher was used to obtain a juice sample from the center of the mid portion internodes, in each millable stalk per row. A hand refractometer was used to determine the rate of soluble solids in the cane juice.

In this experiment, the analysis of variance followed the model of the completely randomized block design, i.e., $\mathrm{Y}_{\mathrm{ij}}=\mathrm{m}+\mathrm{p}_{\mathrm{i}}+\mathrm{s}_{\mathrm{i}}+\mathrm{ps}_{\mathrm{ij}}+\mathrm{b}_{\mathrm{j}}+\mathrm{e}_{\mathrm{ij}}$, where $\mathrm{Y}_{\mathrm{ij}}$ is the observed mean of the $\mathrm{i}^{\text {th }}$ progeny in the $\mathrm{j}^{\text {th }}$ replication; $\mathrm{p}_{\mathrm{i}}$ is a random parental effect; $\mathrm{s}_{\mathrm{i}}$ is a random self effect; $\mathrm{ps}_{\mathrm{ij}}$ are effects of the interaction of the parental with self; $b_{j}$ is a random block effect; and $e_{i j}$ is the experiment error term, assumed to be normally distributed with mean 0 and variance $\theta^{2}$ for testing hypothesis through the F-test. A one-way ANOVA was performed with five variables to determine the existence of variability between parents and self. Only 40 soluble solids were found to be the number of self for each parent, i.e., 10 plants for each replicate.

Depression by inbreeding (DE) was obtained by the means of those attributes, through the 
formula: $\mathrm{DE}(\%)=\left[\left(F 1_{i}-F 2_{i}\right) / F 1_{i}\right] .100$, where, $F 1_{i}$ is the mean of clone $i$, and $F 2_{i}$ is the mean of the generation $F 2$ of clone $i$.

\section{RESULTS AND DISCUSSION}

In the analysis of variance (Table 1) the source of variation for treatment was partitioned into parents and self. Significant differences between parents $(\mathrm{P} \leq 0.01)$ were observed for all traits evaluated. Except for soluble solids, self were highly significant $(\mathrm{P} \leq 0.01)$ for stalk number, height, diameter, and weight. Except for soluble solids which showed no significant differences, there were contrasting differences between parents and self $(\mathrm{P} \leq 0.01)$ in other traits.

The evaluation of the self of 26 varieties is shown in tables 2 and 3 . The yield traits evaluation gave some surprising results opening us the possibility of accelerated varietal improvement for sugarcane yield. Soluble solids results were unexpected and promissory, especially in varieties with poor sugar content such as CTC95-106 (Table 2) and WI78455 (Table 3 ) in which $75.0 \%$ and $62.5 \%$ of progenies exceeded the parental level by a substantial margin. Between the selected inbred lines with high sugar content such as SP88-920, SP90-1517 (Table 2) and SP95-3184 (Table 3), there were 26 (65.0\%), 24 (60.0\%) and $24(60.0 \%)$ offspring, respectively, with higher soluble solids than the parent. HOGARTH (1980) and FERREIRA et al. (2005) also observed that Brix was the trait less affected by inbreeding depression. These results are in accordance with CASSALETT et al. (1996), who observed segregation for sugar yield in varieties with low sugar content such as Co 421.

Low soluble solids variation was observed in SP90-1314 (Table 2) and SP94-3331 (Table 3) inbreds. However, few were superior to original varieties, e.g.
SP92-1583 (Table 3), which has poor level of soluble solids and consequently a poor sugar yield; but there were 21 inbreds (52.5\%) with much higher sugar yield. Combined, these results indicate that sugarcane polyploidy allows the use of inbreeding to either obtain new variation or reassemble a given variety that has agronomically desirable traits but carries few specific defects. Therefore, the superior clones within each line above mentioned could be of interest to enhance soluble solids in breeding process. The high level of heterozygosity in superior clones could be explored in two breeding strategies, such as adoption of these clones in future poly and bi-parental crosses between other genotypes, and, the most innovative, conducting self-pollinations in order to obtain further self generations (F2, F3, etc) and assessing the consequences in sugarcane.

The number of stalks mean in this experiment can be considered below the expected values for number of millable canes, i.e., between 10 to 14 tillers per meter, however, most of the genotypes is constituted by varieties used as parental and not as commercial varieties. But, selfing a variety with high number of stalks (e.g. WI78455, parental mean of 12.3 stalks) produced progenies with a high frequency rate of low number of stalks and progenies with a good frequency (48.5\%), which was superior to the parental mean (Table 3). Conclusively, almost $50 \%$ of progenies obtained by selfing of this variety retained good agronomic characteristics. Segregation for stalk number is another unexpected and promising outcome. Great stalk number in more than $42 \%$ of the progenies clearly demonstrates that the parental variety has expressed the genes that might be useful in reconstructing the variety itself.

A high rate of tall seedlings was observed in SP92-4463, which produced a high frequency $(42.8 \%)$ of taller offspring (Table 3). On the other hand, the

Table 1 - Analysis of variance for five traits of inbreeding in sugarcane varieties tested in one trial.

\begin{tabular}{|c|c|c|c|c|c|c|}
\hline $\begin{array}{l}\text { Source of } \\
\text { variation }\end{array}$ & DF & $\begin{array}{l}\text { Soluble solids } \\
\text { (Brix \% juice) }\end{array}$ & Stalk number & Stalk height & Stalk diameter & Stalk weight \\
\hline Replications & 3 & 6.43 & 14.25 & 0.07 & 0.10 & 13.65 \\
\hline Treatments & 51 & $8.92 *$ & $259.79 * *$ & $7.05^{* *}$ & $4.40 * *$ & $404.16^{* *}$ \\
\hline Parents $(\mathrm{P})$ & 25 & $15.25^{* *}$ & $565.59 * *$ & $6.74 * *$ & $4.80 * *$ & $309.50 * *$ \\
\hline Selfs (S) & 25 & $1.39 \mathrm{~ns}$ & $888.43^{* *}$ & $155.30 * *$ & $90.31 * *$ & $10,349.92 * *$ \\
\hline $\mathrm{P}$ vs $\mathrm{S}$ & 625 & $6.06 \mathrm{~ns}$ & $62.69 * *$ & $0.76^{* *}$ & $0.69 * *$ & $39.55^{* *}$ \\
\hline Residual & 729 & 6.96 & 8.33 & 0.04 & 0.05 & 12.34 \\
\hline Mean & & 17.79 & 7.57 & 1.72 & 2.42 & 6.35 \\
\hline $\mathrm{CV} \%$ & & 14.25 & 49.86 & 15.87 & 13.16 & 58.17 \\
\hline
\end{tabular}

ns - not significant $(\mathrm{P}>0.05)$.

$*$ and ** significant at the probability levels of $\mathrm{P}<0.05$ and $\mathrm{P}<0.01$, respectively. 
Table 2 - Performance of $F_{2}$ populations of 13 sugarcane varieties for five yield traits.

\begin{tabular}{|c|c|c|c|c|c|c|c|c|c|c|c|c|c|c|c|c|}
\hline \multirow[t]{2}{*}{ Parent/self } & \multirow{2}{*}{$\begin{array}{l}\mathrm{N}^{\mathrm{o}} \text { of } \\
\text { selfs }\end{array}$} & \multirow{2}{*}{$M^{3}$} & ----Soluble solids ${ }^{1}$---- & ${ }^{2} \mathrm{~F}_{2}$ superior & \multicolumn{3}{|c|}{----Stalk number---- } & \multicolumn{3}{|c|}{----Stalk height---- } & \multicolumn{3}{|c|}{----Stalk diameter---- } & --- & ${ }^{2} \mathrm{~F}_{2}$ superior & $\begin{array}{l}\text { ght---- } \\
\text { erior }\end{array}$ \\
\hline & & & $\mathrm{N}^{\mathrm{o}}$ & $\%$ & M & $\mathrm{N}^{\mathrm{o}}$ & $\%$ & M & $\mathrm{N}^{\mathrm{o}}$ & $\%$ & M & $\mathrm{N}^{\mathrm{o}}$ & $\%$ & M & $\mathrm{N}^{\mathrm{o}}$ & $\%$ \\
\hline СТC95-106 & - & 14.5 & - & & 7.8 & - & & 1.9 & - & & 2.7 & - & & 8.9 & - & \\
\hline CTC95-106 self & 164 & 15.4 & 30 & 75.0 & 6.9 & 47 & 28.6 & 1.6 & 6 & 3.7 & 2.5 & 27 & 16.5 & 5.5 & 24 & 14.6 \\
\hline IAC89-2135 & - & 17.0 & - & & 9.2 & - & & 1.9 & - & & 2.6 & - & & 9.8 & - & \\
\hline IAC89-2135 self & 172 & 16.7 & 15 & 37.5 & 7.2 & 33 & 19.2 & 1.6 & 26 & 15.1 & 2.4 & 43 & 25.0 & 5.3 & 13 & 7.6 \\
\hline IAC91-2202 & - & 16.6 & - & & 8.0 & - & & 1.9 & - & & 2.4 & - & & 7.4 & - & \\
\hline IAC91-2202 self & 165 & 16.7 & 22 & 55.0 & 7.0 & 50 & 30.3 & 1.6 & 10 & 6.1 & 2.1 & 13 & 7.9 & 4.3 & 22 & 13.4 \\
\hline SP88-869 & - & 19.1 & - & & 6.8 & - & & 1.4 & - & & 2.7 & - & & 6.1 & - & \\
\hline SP88-869 self & 164 & 13.8 & 19 & 47.5 & 7.2 & 66 & 40.2 & 1.1 & 25 & 15.2 & 2.3 & 41 & 25.0 & 3.6 & 28 & 17.1 \\
\hline SP88-919 & - & 17.3 & & & 9.6 & - & & 1.7 & - & & 2.6 & - & & 9.0 & - & \\
\hline SP88-919 self & 170 & 16.8 & 16 & 40.0 & 7.3 & 38 & 22.3 & 1.5 & 37 & 21.8 & 2.2 & 38 & 22.3 & 5.2 & 27 & 15.9 \\
\hline SP88-920 & - & 17.2 & - & & 7.6 & - & & 2.1 & - & & 2.7 & - & & 9.4 & - & \\
\hline SP88 920 self & 173 & 17.8 & 26 & 65.0 & 7.3 & 54 & 31.2 & 1.8 & 23 & 13.3 & 2.3 & 3 & 1.7 & 5.5 & 22 & 12.7 \\
\hline SP89-1116 & - & 19.3 & - & & 7.1 & - & & 2.0 & - & & 3.0 & - & & 9.8 & - & \\
\hline SP89-1116 self & 175 & 19.1 & 20 & 50.0 & 6.0 & 48 & 27.4 & 1.6 & 3 & 2.0 & 2.5 & 6 & 3.4 & 4.8 & 15 & 8.6 \\
\hline SP90-1314 & - & 21.2 & - & & 10.6 & - & & 1.6 & - & & 2.6 & - & & 9.3 & - & \\
\hline SP90-1314 self & 175 & 18.8 & 0 & 0.0 & 8.5 & 42 & 24.0 & 1.3 & 24 & 13.7 & 2.2 & 20 & 11.4 & 4.7 & 13 & 7.4 \\
\hline SP90-1358 & - & 18.6 & - & & 8.9 & - & & 2.0 & - & & 2.6 & - & & 9.6 & - & \\
\hline SP90-1358 self & 165 & 18.3 & 17 & 42.5 & 7.2 & 40 & 24.2 & 1.4 & 3 & 1.8 & 2.3 & 31 & 18.8 & 4.3 & 8 & 4.8 \\
\hline SP90-1428 & - & 17.6 & - & & 5.9 & - & & 1.9 & - & & 3.1 & - & & 8.9 & - & \\
\hline SP90-1428 self & 172 & 16.5 & 8 & 20.0 & 6.6 & 76 & 44.2 & 1.7 & 51 & 29.6 & 2.4 & 8 & 4.6 & 5.7 & 31 & 18.0 \\
\hline SP90-1501 & - & 14.5 & - & & 6.5 & - & & 1.7 & - & & 2.7 & - & & 7.0 & - & \\
\hline SP90-1501 self & 152 & 18.5 & 16 & 40.0 & 5.7 & 36 & 23.7 & 1.2 & 4 & 26.3 & 2.3 & 18 & 11.8 & 3.2 & 10 & 6.6 \\
\hline SP90-1517 & - & 19.8 & - & & 6.7 & - & & 1.8 & - & & 2.7 & - & & 7.2 & - & \\
\hline SP90-1517 self & 168 & 19.9 & 24 & 60.0 & 5.6 & 45 & 26.8 & 1.3 & 13 & 7.7 & 2.2 & 15 & 8.9 & 3.6 & 19 & 11.3 \\
\hline SP90-1616 & - & 18.2 & - & & 10.1 & - & & 1.6 & - & & 2.7 & - & & 9.5 & - & \\
\hline SP90-1616 self & 175 & 18.7 & 21 & 52.5 & 7.4 & 36 & 20.5 & 1.4 & 43 & 24.6 & 2.2 & 7 & 4.0 & 4.7 & 13 & 7.4 \\
\hline
\end{tabular}

${ }^{1}$ Only for soluble solids (Brix \% juice), 40 was the number of selfs for each parent.

${ }^{2}$ Number of $F_{2}$ better than parental.

${ }^{3}$ Mean of the trait evaluated.

progeny of SP90-1358, which is moderately tall (average $1.4 \mathrm{~cm}$ ), produced $1.8 \%$ tall lines (Table 2). Although it is possible to find clones in the progeny with higher means that the parent variety, and a selfing effect was observed on stalk height, because progeny means were always lower than parent means.

Selfing varieties with high diameter of the stalks (i.e. SP89-1116, parental mean diameter of $3.0 \mathrm{~cm}$ ), produced progenies with very low average stalk diameter (Table 2). Only six seedlings, i.e, $3.4 \%$ of progenies, were obtained with superior diameter to the parental average. On the other hand, the progeny SP953184 (Table 3), which has moderate diameter size, (parental mean, $2.7 \mathrm{~cm}$ ) produced diameter lines $30.8 \%$ superior. But, in a general way, selfing promoted reduction in average stalk diameter.

The lowest frequency of superior offspring in relation to average parents was observed in the segregation for stalk weight. Except for genotype WI78455 (Table 3), in which many progenies (40) exceeded the parental level by a substantial margin. Biometric agronomic traits are important in the final weight components of sugarcane stalks (SILVA et al., 2008). If any of the production components were affected by selfing, then stalk weight determination is expected to be affected.

The most promising results were obtained in WI78455 where besides being the most important in stalk number and stalk weight, with high frequency of superior clones for soluble solids, the inbreeds retained the excellent agronomic characteristics of their progenitor. The wide segregation for stalk height and stalk diameter permitted the selection of $27.8 \%$ and $17.8 \%$, respectively, above the parental mean. CASSALETT et al. (1996) also found few inbred lines of CP57-603 that retained excellent agronomic 
Table 3 - Performance of $\mathrm{F}_{2}$ populations of 13 sugarcane varieties for five yield traits.

\begin{tabular}{|c|c|c|c|c|c|c|c|c|c|c|c|c|c|c|c|c|}
\hline \multirow{3}{*}{ Parent/self } & \multirow{3}{*}{$\begin{array}{l}\mathrm{N}^{\mathrm{o}} \text { of } \\
\text { selfs }\end{array}$} & \multicolumn{3}{|c|}{----Soluble solids ${ }^{1}----$} & \multirow{2}{*}{\multicolumn{3}{|c|}{$\begin{array}{l}---- \text { Stalk number---- } \\
\quad{ }^{2} F_{2} \text { superior }\end{array}$}} & \multirow{2}{*}{\multicolumn{3}{|c|}{$\begin{array}{l}\text {----Stalk height---- } \\
{ }^{2} \mathrm{~F}_{2} \text { superior }\end{array}$}} & \multirow{2}{*}{\multicolumn{3}{|c|}{$\begin{array}{l}\text {----Stalk diameter---- } \\
\quad{ }^{2} \mathrm{~F}_{2} \text { superior }\end{array}$}} & \multirow{2}{*}{\multicolumn{3}{|c|}{$\begin{array}{l}\text {----Stalk weight---- } \\
\quad{ }^{2} \mathrm{~F}_{2} \text { superior }\end{array}$}} \\
\hline & & \multirow{2}{*}{$\mathrm{M}^{3}$} & \multicolumn{2}{|c|}{${ }^{2} \mathrm{~F}_{2}$ superior } & & & & & & & & & & & & \\
\hline & & & $\mathrm{N}^{\mathrm{o}}$ & $\%$ & M & $\mathrm{N}^{\mathrm{o}}$ & $\%$ & M & $\mathrm{N}^{\mathrm{o}}$ & $\%$ & M & $\mathrm{N}^{\mathrm{o}}$ & $\%$ & M & $\mathrm{N}^{\mathrm{o}}$ & $\%$ \\
\hline SP90-3588 & - & 18.3 & - & & 8.3 & - & & 2.0 & - & & 2.7 & - & & 9.7 & - & \\
\hline SP90-3588 self & 165 & 17.3 & 12 & 30.0 & 7.8 & 59 & 35.7 & 1.6 & 6 & 3.6 & 2.3 & 15 & 9.1 & 5.5 & 19 & 11.5 \\
\hline SP91-3637 & - & 17.3 & - & & 8.1 & - & & 2.1 & - & & 2.6 & - & & 8.8 & - & \\
\hline SP91-3637 self & 172 & 17.6 & 23 & 57.5 & 7.1 & 54 & 31.4 & 1.7 & 23 & 13.4 & 2.2 & 21 & 12.2 & 4.9 & 23 & 13.4 \\
\hline SP92-1548 & - & 17.5 & - & & 9.2 & - & & 2.0 & - & & 2.6 & - & & 10.1 & - & \\
\hline SP92-1548 self & 175 & 17.2 & 15 & 37.5 & 9.1 & 69 & 39.4 & 1.7 & 29 & 16.6 & 2.3 & 34 & 19.4 & 7.1 & 29 & 16.6 \\
\hline SP92-1583 & - & 14.3 & - & & 7.2 & - & & 2.1 & - & & 2.6 & - & & 8.2 & - & \\
\hline SP92-1583 self & 155 & 18.7 & 21 & 52.5 & 6.4 & 48 & 31.0 & 1.7 & 9 & 5.8 & 2.3 & 29 & 18.7 & 5.0 & 27 & 17.4 \\
\hline SP92-3796 & - & 19.2 & - & & 7.5 & - & & 2.0 & - & & 2.9 & - & & 9.8 & - & \\
\hline SP92-3796 self & 172 & 19.1 & 20 & 50.0 & 6.1 & 33 & 19.2 & 1.6 & 12 & 7.0 & 2.5 & 20 & 11.6 & 4.9 & 12 & 7.0 \\
\hline SP92-4461 & - & 19.3 & - & & 5.7 & - & & 1.7 & - & & 2.6 & - & & 6.0 & - & \\
\hline SP92-4461 self & 165 & 19.1 & 19 & 47.5 & 5.1 & 44 & 26.7 & 1.4 & 16 & 9.7 & 2.3 & 62 & 6.7 & 4.0 & 27 & 16.4 \\
\hline SP92-4463 & - & 18.4 & - & & 6.7 & - & & 1.7 & - & & 2.5 & - & & 6.0 & - & \\
\hline SP92-4463 self & 166 & 17.6 & 11 & 27.5 & 6.2 & 62 & 37.3 & 1.3 & 71 & 42.8 & 2.2 & 5 & 3.0 & 4.9 & 34 & 20.5 \\
\hline SP94-1275 & - & 18.4 & - & & 9.1 & - & & 1.8 & - & & 2.6 & - & & 8.7 & - & \\
\hline SP94-1275 self & 163 & 18.1 & 16 & 40.0 & 7.4 & 41 & 25.1 & 1.3 & 4 & 24.5 & 2.2 & 23 & 14.1 & 3.9 & 10 & 6.1 \\
\hline SP94-3331 & - & 19.2 & - & & 8.1 & - & & 1.7 & - & & 2.6 & - & & 7.4 & - & \\
\hline SP94-3331 self & 170 & 17.6 & 3 & 7.5 & 7.0 & 48 & 28.2 & 1.4 & 40 & 23.5 & 2.4 & 49 & 28.8 & 4.8 & 29 & 17.1 \\
\hline SP94-3374 & - & 17.7 & - & & 7.3 & - & & 2.0 & - & & 2.5 & - & & 7.5 & - & \\
\hline SP94-3374 self & 161 & 17.8 & 21 & 52.5 & 6.1 & 52 & 32.3 & 1.6 & 8 & 5.0 & 2.3 & 32 & 19.9 & 4.5 & 27 & 16.8 \\
\hline SP95-1005 & - & 17.3 & - & & 6.8 & - & & 1.9 & - & & 2.7 & - & & 7.8 & - & \\
\hline SP95-1005 self & 169 & 17.5 & 20 & 50.0 & 6.1 & 53 & 31.4 & 1.5 & 15 & 8.9 & 2.3 & 33 & 19.5 & 4.1 & 14 & 8.3 \\
\hline SP95-3184 & - & 18.6 & - & & 6.6 & - & & 1.9 & - & & 2.7 & - & & 7.0 & - & \\
\hline SP95-3184 self & 159 & 19.0 & 24 & 60.0 & 5.2 & 32 & 20.1 & 1.4 & 20 & 12.6 & 2.4 & 49 & 30.8 & 3.8 & 23 & 14.5 \\
\hline WI78455 & - & 15.5 & - & & 12.3 & - & & 1.8 & - & & 2.3 & & & 9.5 & & \\
\hline WI78455 self & 165 & 15.9 & 25 & 62.5 & 13.1 & 80 & 48.5 & 1.6 & 36 & 27.8 & 1.9 & 29 & 17.6 & 7.1 & 40 & 24.2 \\
\hline
\end{tabular}

${ }^{1}$ Only for soluble solids (Brix \% juice), 40 was the number of selfs for each parent.

${ }^{2}$ Number of $F_{2}$ better than parental.

${ }^{3}$ Mean of the trait evaluated.

characteristics of their parents, besides resistance to rust and mosaic.

According to RAO (2007 - Personal Communication), W178455 is very vigorous with many thin canes in Barbados. The good results obtained in this research may be due to the fact that there is a complex inter specific hybrid with Saccharum noble and Saccharum spontaneum species involved with one noble and two $S$. spontaneum. So, the parentage of this variety is BNS2211 (backcross) X SES602 ( $S$. spontaneum). BNS2211 parents are B244 (noble) X Unknown noble X S. spontaneum $\mathrm{F}_{1}$ hybrid. Therefore, the superior clones within this progeny could be used to explore heterosis in crosses between parental and/ or parallel, that should be continued to obtain the following generation inbred lines.

The inbreeding depression estimates (Table 4) obtained for soluble solids, stalk number, stalk height, stalk diameter and stalk weight were compatible with the reported estimates in the literature for yield characters in other crops. The null values are those that resulted in negative depression. Soluble solids values varied around $0.26 \%$ for the self of SP92-3796 and $27.48 \%$ for the self of SP88-869. For stalk number, the values obtained were between the smallest $(0.86 \%)$ and the largest $(26.83 \%)$ for the self-crossings SP921548 and SP90-1616, respectively. Stalk height values were $9.88 \%$ in SP88-919 and 32.75\% in the self SP901501. The values for stalk diameter varied between $7.38 \%$ and $22.11 \%$, being the smallest obtained for the self CTC95-106 and the largest for the self SP90-1428. The largest values for that estimate were found for stalk weight that varied between 19.37 and $54.99 \%$ for the self-crossings of SP92-4463 and SP90-1358, respectively. In maize, NASS \& MIRANDA FILHO (1995) reported an inbreeding depression of the order of $13.7 \%$ and $12.8 \%$ for plant height, $15.9 \%$ and $14.2 \%$ for ear height and $19.4 \%$ and $12.7 \%$ for tassel branch number. 
Table 4 - Estimate of the depression for inbreeding of 26 crossings sugarcane self for soluble solids, stalk number, height, diameter and weight.

\begin{tabular}{|c|c|c|c|c|c|}
\hline Parent/self & $\begin{array}{l}\text { Soluble solids } \\
\text { (Brix \% juice) }\end{array}$ & Stalk number & Stalk height & Stalk diameter & Stalk weight \\
\hline CTC95-106 / self & 0.00 & 11.69 & 18.75 & 7.38 & 37.75 \\
\hline IAC89-2135 / self & 2.05 & 22.34 & 13.83 & 10.60 & 45.44 \\
\hline IAC91-2202 / self & 0.00 & 11.71 & 18.97 & 13.46 & 41.37 \\
\hline SP88-869 / self & 27.48 & 0.00 & 21.37 & 13.85 & 41.43 \\
\hline SP88-919 / self & 2.60 & 24.29 & 9.88 & 13.12 & 42.25 \\
\hline SP88-920 / self & 0.00 & 3.54 & 15.38 & 17.81 & 41.40 \\
\hline SP89-1116 / self & 0.77 & 15.01 & 20.20 & 17.45 & 51.01 \\
\hline SP90-1314 / self & 11.40 & 20.26 & 16.25 & 15.76 & 49.73 \\
\hline SP90-1358 / self & 1.77 & 19.55 & 28.57 & 12.69 & 54.99 \\
\hline SP90-1428 / self & 5.80 & 0.00 & 11.70 & 22.11 & 35.54 \\
\hline SP90-1501 / self & 0.00 & 11.24 & 32.75 & 16.05 & 53.98 \\
\hline SP90-1517 / self & 0.00 & 15.69 & 25.14 & 18.24 & 49.79 \\
\hline SP90-1616 / self & 0.00 & 26.83 & 11.72 & 16.97 & 50.78 \\
\hline SP90-3588 / self & 5.29 & 6.10 & 22.00 & 12.96 & 43.03 \\
\hline SP91-3637 / self & 0.00 & 12.36 & 18.35 & 13.23 & 43.86 \\
\hline SP92-1548 / self & 1.71 & 0.86 & 10.71 & 11.74 & 29.88 \\
\hline SP92-1583 / self & 0.00 & 11.28 & 20.09 & 11.78 & 38.87 \\
\hline SP92-3796 / self & 0.26 & 19.38 & 18.36 & 12.84 & 50.00 \\
\hline SP92-4461 / self & 1.18 & 9.17 & 14.20 & 10.54 & 33.16 \\
\hline SP92-4463 / self & 4.60 & 8.01 & 21.30 & 14.90 & 19.37 \\
\hline SP94-1275 / self & 1.62 & 18.65 & 25.86 & 14.06 & 52.90 \\
\hline SP94-3331 / self & 8.22 & 13.98 & 16.16 & 8.07 & 34.60 \\
\hline SP94-3374 / self & 0.00 & 16.59 & 21.00 & 8.30 & 40.21 \\
\hline SP95-1005 / self & 0.00 & 10.94 & 20.41 & 14.92 & 47.56 \\
\hline SP95-3184 / self & 0.00 & 20.73 & 22.04 & 8.27 & 45.58 \\
\hline WI78455 / self & 0.00 & 0.00 & 10.38 & 17.98 & 25.07 \\
\hline Mean & 2.87 & 12.70 & 18.67 & 13.66 & 42.16 \\
\hline
\end{tabular}

Both stalk height and stalk weight showed to be subjected to fairly strong inbreeding depression. References were not found on depression values for inbreeding in sugarcane; however, MCINTYRE \& JACKSON (2001) demonstrated that inbreeding depression is relatively low in sugarcane and that it is possible to obtain superior inbred lines from selfing. According to the present study, inbred lines should not be adopted as breeding strategy to obtain commercial genotypes, but they could be used for creating hybrid vigor on crossing clones derived from selfing. HOGARTH (1980) observed that effects of selfing are much more important to express the specific combining ability (S.C.A.) than general combining ability (G.C.A.) effects for most characters. FERREIRA et al. (2005) recommended the use of inbred lines as one more alternative for the formation of base populations for programs of reciprocal recurrent selection.
The inbreeding depression differed between crossings. Considering the effect of self-pollination on the levels of soluble solids, the depression was more pronounced for the self obtained from SP88-869 and SP90-1314, while depression was null for the selfpollinations of CTC95-106, IAC91-2202, SP88-920, SP901501, SP90-1517, SP90-1616, SP91-3637, SP92-1583, SP94-3374, SP95-1005, SP95-3184, WI78455. The largest inbreeding depression values for stalk number were found in IAC89-2135, SP88-919, SP90-1314, SP90-1358, SP90-1616, SP92-3796, SP94-1275, SP95-3184 selffertilizations, while inbreeding depression values for SP88-869, SP90-1428 and WI78455 self fertilizations were null. There was no null value for inbreeding depression in stalk height. The higher inbreeding depression values obtained after self-fertilization were for SP90-1358, SP90-1501, SP90-1517 and SP94-1275. Also, no null values were obtained for inbreeding in stalk diameter, and only the self-pollination of SP901468 resulted in higher depression (22.1\%). 
Null inbreeding depression values were also not found for stalk weight, and the means of SP891116, SP90-1314, SP90-1358, SP90-1501, SP90-1517, SP90-1616, SP92-3796 and SP94-1275 self-fertilizations were the highest among all parameters. These results indicate that self-pollinations with higher depressions within each parameter have more heterozygous loci than null or low depression self.

\section{CONCLUSION}

It is possible to segregate different traits in a given sugarcane variety and find lines with promising outcome for all assessed characteristics, with soluble solids and stalk number showing the widest segregation level. Self-pollination did not produce a general loss in yield traits, therefore selfing-derived clones can be used to produce hybrid vigor in crossings.

\section{PERSONAL COMMUNICATION}

RAO, P.S. West Indies Central Sugar Cane Breeding Station WICSCBS - Groves, St. George, BB19073, Barbados, W.I. E-mail: info@wicscbs.org.

\section{ACKNOWLEDGEMENTS}

M. de A. Silva and P. de S. Gonçalves are fellowship holders of the Conselho Nacional de Desenvolvimento Científico e Tecnológico (CNPq).

\section{REFERENCES}

ALLARD, R.W. Princípios do melhoramento genético das plantas. São Paulo: Edgard Blüchner, 1971. 381p.

AMAYA, E.A. Mejoramiento de la caña de azúcar. In: BUENAVENTURA, C. (Ed.). El cultivo de la caña de azúcar. Cali: Tecnicaña, 1986. p.41-52.

CASSALETT, C.A. et al. Self-pollination in sugarcane hybrids, Saccharum sp. In: INTERNATIONAL SOCIETY OF SUGARCANE TECHNOLOGISTS CONGRESS, 22., 1995, Carthagena. Proceedings... Carthagena: ISSCT, 1996. p. 312-315.
ETHIRAJAN, A.S. et al. Studies on successive inbred generations of selected sugarcane cultivars. In: INTERNATIONAL SOCIETY OF SUGARCANE TECHNOLOGISTS CONGRESS, 16., 1977, São Paulo. Proceedings... São Paulo: ISSCT, 1978. p.269-273.

FERREIRA, F.M. et al. Effects of inbreeding on the selection of sugar cane clones. Crop Breeding and Applied Biotechnology, v.5, p.174-182, 2005

HALLAUER, A.R. Methods used in developing maize inbreeds. Maydica, v.35, p.1-16, 1990.

HOGARTH, D.M. The effect of accidental selfing on the analysis of a diallel cross with sugar cane. Euphytica, v.29, p.737-746, 1980. Available from: <http://www.springerlink.com/content/ mg17rm3154842141/>. Accessed: Nov. 9, 2010. doi: 10.1007/ BF00023220.

LANDELL, M.G.A.; SILVA, M.A. As estratégias de seleção da cana em desenvolvimento no Brasil. Visão Agrícola, v.1, p.18-23, 2004.

MCINTYRE, C.L.; JACKSON, P.A. Low level of selfing found in a sample of crosses in Australian sugarcane breeding programs. Euphytica, v.117, p.245-249, 2001. Available from: <http:// www.springerlink.com/content/v705q8464h03687 m/>. Accessed: Nov. 9, 2010. doi: 10.1023/A:1026527617892.

NASS, L.L.; MIRANDA FILHO, J.B. Inbreeding depression rates of semi-exotic maize (Zea mays L.) population. Revista Brasileira de Genética, v.18, p.585-592, 1995.

SILVA, M. de A. et al. Yield components as indicators of drought tolerance of sugarcane. Scientia Agricola, v.65, p.620627, 2008. Available from: <http://www.scielo.br/ s c i e 1 o.p h p ? s c r i p t $=$ s c i _ p d f \& p i d = S $0103-$ $90162008000600008 \& \operatorname{lng}=$ pt\&n $\mathrm{rm}=\mathrm{iso} \& \operatorname{tng}=\mathrm{en}>$. Accessed: Nov. 8, 2010. doi: 10.1590/S0103-90162008000600008.

STEVENSON, G.C. The use of selfing and inbreeding in sugarcane. In: INTERNATIONAL SOCIETY OF SUGAR CANE TECHNOLOGISTS CONGRESS, 8., 1953, Bridgetown: Proceedings... Bridgetown: ISSCT, 1953. p.509-520.

STEVENSON, G.C. Genetics and breeding of sugarcane London: Longmans Green, 1965. 284p.

VEGA, O.U.A. Mejoramiento genético de las plantas. Maracay, v.33, p.119-151, 1988.

WARNER, J.N. The evaluation of a philosophy on sugar cane breeding in Hawaii. Hawaii Plant Record, v.54, p.322-335, 1953. 